\title{
Risks and coping strategies of production and marketing of cocoa in Ondo State, Nigeria
}

\author{
Folaranmi D. Babalola, Opeyemi E. Ayinde, Paxie W. Chirwa, Djiby R. Thiam
}

\begin{abstract}
In recent time, yields from cocoa producing states have been decreasing while farmers are faced with a number of challenges that predispose them to risks and uncertainties. The study therefore assessed the major production and marketing risks in Ondo State, Nigeria. The socio-economic characteristics of the cocoa farmers were analysed using descriptive analysis while Kruskal-Wallis ranking analysis was used to assess the farmer's perception on sources of risks. Ranking on top of the ten identified cocoa production risks was pest and diseases attack while undue exploitation by exporters ranked on top of marketing risks. The major coping strategies adopted by the farmers of the cocoa include diversifi-cation of production system by growing substitute crops (47.5\%), and involvement in non-farm business to generate additional income (35.0\%). In other to reduce risks faced by the farmers, government should put in place a marketing scheme aimed at assisting cocoa farmers through price regulation and monitoring. Cocoa farmers also needed to be introduced to the current technologies of production with the provision of necessary incentives such as improved varieties of cocoa seedling, as well as provision of fertiliser and approved pesticides, financial assistance, and simple processing technologies that produce standard cocoa beans.
\end{abstract}

\section{Keywords}

Risks, Price regulation, Market chain, Coping strategy, Cocoa agroforest

F. D. Babalola $(\bowtie)$

Department of Forest Resources Management, University of Ilorin, Ilorin, Nigeria

e-mail: fola.babalola@up.ac.za;

folababs2000@gmail.com

O. E. Ayinde

Department of Agricultural Economics and Farm

Management, University of Ilorin, Ilorin, Nigeria

F. D. Babalola · P. W. Chirwa

Forest Science Postgraduate Programme, University of Pretoria, 5-15 Plant Sciences Complex, Pretoria,

South Africa

D. R. Thiam

Centre for Development Research (ZEF), University of Bonn, Bonn, Germany

D. R. Thiam

School of Economics, University of Cape Town, Private

Bag X3, Rondebosch 7701, South Africa

\section{Introduction}

About 20 million people depend on cocoa for their livelihood with $90 \%$ of cocoa production coming from smallholder farms of under 5 ha (FTEM 2008; EUFIC 1999). However, various studies on cocoa production and marketing have revealed that cocoa sector is faced with a number of risks and uncertainties (Gockowski 2007; Vigneri 2007; Fantazy et al. 2010; Otchere et al. 2013; Sarpong et al. 2013). Production 
and marketing of agricultural products follow the path of supply and/or value chain. Therefore, it is important to link the level and the scale of the risks assessed with the value chain of the products from production to harvest, transport, distribution and consumption. Indeed, due to the nature of the crop, there are a number of challenges constituting risks as the product is moved and exchanged along the chain.

On the international market, the demand for cocoa is increasing due to the boom in the chocolate consumption, aside other uses of cocoa, whereas the cocoa production is declining from the producing states. From the production estimates of International Cocoa Organisation (ICCO 2013), global cocoa production has decreased from 4.3 million metric tonnes in 2010/2011 to 4.0 million metric tonnes in 2011/2012 and 3.9 million metric tonnes in 2012/13. The International Cocoa Organization (ICCO) forecasts a shortfall of about 50,000 tons in 2013, while Parkin and Mars (two of the major processing industries of cocoa) has estimated that demand for cocoa will outpace production by 1 million tonnes by the end of the decade. The prices of cocoa has also been decreasing mainly due to stock/grind ratios, global food prices, and fragmentation in cocoa trade and processing industries (WCF 2012). It has also been estimated that around $30 \%$ of the cocoa crop world-wide is lost to pest and disease attack (EUFIC 1999). Such attacks reduce cocoa productivity and hence lower the supply for both the internal and international markets. Chemical treatment is however not always possible, due either to the nature of the pests or because the chemicals are too expensive for most farmers and lower the international standard of the beans as a result of contamination. The heavy use of pesticides is also compounded by their contribution to environmental pollution and health risks to farmers (EUFIC 1999). These are all factors contributing to risks and future uncertainties of cocoa and therefore need serious attention.

As at 2012, the global chocolate confectionery market was reported to attain net sales of approximately 80 billion dollars, which is estimated to increase to 88 billion dollars in 2014 (MCF 2013). However, from the assessment of the prices along cocoa marketing chain, local cocoa producers received the least profit (Fold 2002). For instance, it was discovered that producers of cocoa received only about $6 \%$ of the price that consumers in rich countries pay for chocolate. Farmers in Ivory Coast have been reported to receive only $40-50 \%$ of the world market price for their cocoa beans. Generally, many of the cocoa farmers and workers are found to be living below threshold of absolute poverty with less than USD1.25 a day (MCF 2013). These issues may not be unconnected with low level of development in producing countries.

Cocoa farmers do not have well organised marketing systems in most of the West African countries where about $70 \%$ of the cocoa is produced. The farmers also lack information into market trend for cocoa prices. The consequences of price volatility, together with increasing production costs, have been contributing to economic insecurity and impoverishment for millions of cocoa farmers (MCF 2013). Moreover cocoa producers receive the smallest part of the price paid by consumers in rich countries due to low price transmission between producers and export markets. For instance since the liberalization of the cocoa sector in Nigeria in 1986, the structure of the cocoa market has changed over time to form a monopoly situation in which prices are fixed by few companies responsible for the marketing of the cocoa beans. Since farmers don't have enough technical, human and financial facilities to conserve the beans produced at farm level, they sell them at prices fixed by intermediaries from local buying agents (LBAs). Such prices proposed to cocoa producers are far below the prices at the international markets. However it is argued that when farmers are members of cooperatives, they have more bargaining power and therefore they can achieve higher profits since they can negotiate better prices with the intermediaries (Cadoni 2013).

As reported by Almeida and Monnier (2013), the issues of price volatility, yield reduction over the years, small holding farms that are not economical, and lucrative nature of alternative crops such as rubber are making cocoa farmers in West Africa to abandon their cocoa farms. Furthermore, cocoa sector is faced with poor levels of investment in infrastructure and this has been undermining the efficiency of the sector's value chain and cause supply disruptions. These are all posing risks and uncertainties to the future of cocoa, hence challenges to the millions of people that rely on the proceeds of the crop as source of livelihoods.

Many nations around the world whose economies depend on oil have been looking for alternative sources of revenue generation because of the uncertainties in the future of oil as well as its non-renewable 
nature. Cocoa is now produced in small farms characterised with low yields. Many of the farmers have also started abandoning their cocoa farms for other crops. Top on the concerns for cocoa sector in Nigeria is the lack of support for the local farmers and development of the processing sub-sector (Hamzat et al. 2006). Beside these concerns, cocoa farmers are also facing risks that arise from different sources, which affect negatively their productions and livelihoods. The risks faced by farmers can take economic, physical, environmental and social forms. Therefore the purpose of this study is to identify the major risks faced by farmers in their production and marketing of cocoa in Nigeria with focus on Ondo state, which is the highest producing state in the country. In doing so we use qualitative and quantitative information collected from questionnaires administered to cocoa farmers in the region. The risks are identified in considering heterogeneity of farmers in terms of genders, scales of production and number of hectares. Moreover, this study provides coping strategies that farmers might develop to reduce the risks associated with production and marketing of cocoa in the study area.

\section{Methodology}

Study area

Cocoa is produced in the rainforest zone of Nigeria, within the area known as Cocoa Belt. The main cocoa producing States located within this belt include Akwa Ibom, Cross River, Delta, Edo, Ekiti, Ogun, Ondo, and Oyo. Among these States, Ondo State, located in Southwest Nigeria, produced over $50 \%$ of the cocoa (Adegeye 1996). The study was therefore conducted in Ondo State. Ondo State lies between latitudes $5^{\circ} 45^{\prime}$ and $7^{\circ} 52^{\prime}$ north of the equator and longitudes $4^{\circ} 20^{\prime}$ and $6^{\circ} 5^{\prime}$ east of Greenwich Meridian. The State is typically an agrarian society due to its favourable ecological and climatic conditions. The climate of the State is tropical monsoon with two distinct seasonsthe rainy season (April-October) and dry season (November-March). Humidity is high during the rainy season and low during the Harmattan period of the dry season (Oke and Odebiyi 2007; Adekunle et al. 2013). The vegetation of the State ranges from mangroves swamps in the south, to rainforest in the mid-land and derived savannah in the north. The southern zone of the State is where agricultural tree crops like cocoa, rubber, oil palm, and cashew are planted in abundance.

\section{Data collection}

The study is a survey of cocoa farmers sampled at household level. Primary data used for the data was collected through administration of structured questionnaire. The questionnaire was structured to collect information on socio-economic of cocoa farmers in selected local government in Ondo State and risk associated with cocoa production and marking. Specifically, for the production of cocoa, the questionnaire was structured to collect information on the area of cocoa farms and how the farmers obtained the land on which the farms are existing; type of cultural practices adopted in improving the yield of their cocoa trees, most especially fertiliser application; and type of labour employed by the farmers on their cocoa farms. The questionnaire also contained a number of pre-determined list of risks for the farmers to indicate the one that is most applicable to their production and marketing of the cocoa. Prior to the actual study, reconnaissance surveys were conducted to determine the production and marketing risks encountered by the cocoa farmers. Also, the coping strategies employed by the farmers were compiled. The list of compiled production and marketing risks, as well as the coping strategies, were subjected to ranking using their corresponding percentage of occurrence. The most frequently risks mentioned by the farmers and coping strategies were then compiled for the final questionnaire.

Multistage sampling technology was used for the selection of the farmers. Four local government areas were chosen from Ondo State and these include: Ileoluji/Oke-Igbo, Ondo West, Ose and Idanre. Virtually, all the local communities within these LGAs are involved in cocoa production. Therefore, two communities were randomly selected from each of the LGAs for the survey. The selected communities include Lomitutu, Bagbe, Lajee, Ajue, Tekule, Litaye, Oluwasola, Lalepa. Systematic sampling of houses along roads in the selected communities was adopted for the survey. For each of the major roads in the communities, the third houses on the left and right were sampled. In each of the households, the questionnaire was administered to the heads that owned cocoa plantation. Data generated from the questionnaire administered in the eight selected communities were pooled together for the final analysis. 
Data analysis

The socio-economic characteristics of the cocoa farmers was analysed using descriptive analysis such as frequency and percentages. Kruskal-Wallis ranking analysis was used to assess the farmer's perception on sources of risks associated with cocoa production and marketing. The Kruskal-Wallis test is a non-parametric test and it assigns ranks $R_{i}$ to the different combined observations $n_{i}$. To apply the test one needs at least two independent groups of observations. The equation for estimating the ranks (Wayne 1990) is outlined thus:

$H=\frac{12}{(N+1)} \sum_{i=1} n i \frac{1}{n i} \frac{[R i-n i(\mathrm{~N}+1)}{2}$

where Ri sum of the ranks assigned to observation in the ith sample, $\mathrm{N}$ total number of observations, $n_{i}$ number of observations in groups $\mathrm{i}, \frac{n i(N+1)}{2}$ expected sum of ranks for the ith treatment.

\section{Results}

Socio-economic characteristics of the cocoa farmers

Majority of the cocoa farmers were male (91.67\%), married $(74.16 \%)$ and within the age bracket of 41-80 years $(75.0 \%)$. The highest form of education undergone by $42.5 \%$ of the farmers was primary education, closely followed by those that did not have any form of formal education $(41.7 \%)$. More than three quarter of the farmers $(79.2 \%)$ had household size ranging from 6 to 17 individuals. The average number of year that the farmers have been involved in cocoa farming was 37.5 years. Almost three quarters of the farmers $(74.2 \%)$ belong to farmer's cooperatives, and $65.0 \%$ of them have other sources of income (off-farm activities) in addition to coca farming (Table 1).

Production factors for cocoa agroforest in Ondo State

Table 2 shows some of the production factors employed by the cocoa farmers. Large proportion of the land used for cocoa production in the communities
Table 1 Socio economic characteristics of cocoa farmers in Ondo State Nigeria

\begin{tabular}{|c|c|c|}
\hline Variables & Freq. $(\mathrm{n}=120)$ & Percent \\
\hline \multicolumn{3}{|l|}{ Gender } \\
\hline Male & 110 & 91.7 \\
\hline Female & 10 & 8.3 \\
\hline \multicolumn{3}{|l|}{ Marital status } \\
\hline Single & 7 & 5.8 \\
\hline Married & 89 & 74.2 \\
\hline Divorced & 0 & 0 \\
\hline Widowed & 24 & 20.0 \\
\hline \multicolumn{3}{|l|}{ Age category } \\
\hline $21-40$ & 30 & 25.0 \\
\hline $41-60$ & 54 & 45.0 \\
\hline $61-80$ & 36 & 30.0 \\
\hline \multicolumn{3}{|l|}{ Household size } \\
\hline $0-5$ & 23 & 19.2 \\
\hline $6-11$ & 59 & 49.2 \\
\hline $12-17$ & 36 & 30.0 \\
\hline $18-23$ & 2 & 1.6 \\
\hline \multicolumn{3}{|c|}{ Other sources of income } \\
\hline Yes & 78 & 65.0 \\
\hline No & 42 & 35.0 \\
\hline \multicolumn{3}{|l|}{ Education } \\
\hline Primary & 51 & 42.5 \\
\hline Secondary & 14 & 11.7 \\
\hline Tertiary & 5 & 4.1 \\
\hline No formal & 50 & 41.7 \\
\hline \multicolumn{3}{|c|}{ Membership of cooperative } \\
\hline Member & 31 & 25.8 \\
\hline Non-member & 89 & 74.2 \\
\hline \multicolumn{3}{|c|}{ Farming experience } \\
\hline $1-15$ & 30 & 25.0 \\
\hline $16-30$ & 31 & 25.8 \\
\hline $31-45$ & 48 & 40.0 \\
\hline
\end{tabular}

was inherited $(65.8 \%)$, although $30.8 \%$ of the farmers indicated that they purchased their land. Very few farmers rented $(1.7 \%)$ and borrowed $(1.7 \%)$ their lands while none used communal land for cocoa production. Furthermore, the size of majority of the cocoa plantations ranged between 6 and 15 hectares, meaning that majority of the production was at small scale level. More than three quarters of the farmers (76.7\%) did not apply any fertiliser to their cocoa 
Table 2 Production factors for cocoa agroforest in Ondo State Nigeria

\begin{tabular}{lcl}
\hline Variables & Freq. $(\mathrm{n}=120)$ & Percent \\
\hline Area of cocoa plantation & (hectares) & \\
$1-5$ & 5 & 4.2 \\
$6-10$ & 55 & 45.8 \\
$11-15$ & 52 & 43.3 \\
$16-20$ & 3 & 6.7 \\
Type of fertilizer used by the farmers & \\
Organic & 18 & 15 \\
Inorganic & 10 & 8.3 \\
None & 92 & 76.7 \\
Mode of land acquisition & \\
Rented & 2 & 1.7 \\
Inherited & 79 & 65.8 \\
Purchased & 37 & 30.8 \\
Borrowed & 2 & 1.7 \\
Community & 0 & 0 \\
Types of labour employed by farmers & 65.8 \\
Family & 79 & 34.2 \\
Hired & 41 & 0 \\
Communal & 0 &
\end{tabular}

trees, and majority employed family labour $(65.8 \%)$ for their plantation operations.

Farmers' perception of major sources of risks in production and marketing of cocoa

The perceptions of cocoa farmers with respect to risks in the production and marketing of cocoa were assessed using Kruskal-Wallis One Way Analysis of Variance. The results of the tests were used in ranking the risks as presented in Tables 3 and 4 for production and marketing respectively. All the assessed ten risks associated with cocoa production and the five risks associated with cocoa marketing were significant $(\mathrm{p}<0.001)$.

Ranking on top of the production risks was 'damage by pests and diseases' with mean value of 105.5. This was followed by other significant factors such as dependent on weather condition (mean $=95.5$ ), lack of subsidies on agrochemicals (mean $=91.5$ ), expensive inputs $($ mean $=91.0)$, and old methods of farming (mean $=90.5)$. The least ranked risk was lack of technical knowledge in production process (mean $=65.5)$. On the other hand, exploitation of the farmers by middlemen (local wholesalers and exporters) ranked topmost among the marketing risks of cocoa $($ mean $=101.2)$, followed by inconsistence and fluctuation in pricing system (mean $=93.7)$, and high cost of marketing (mean $=71.9$ ) of cocoa beans. Ranking at the bottom of marketing risks was lack of market information $($ mean $=60.2)$.

\section{Coping strategies for risks in cocoa farming}

The coping strategies adopted by the cocoa farmers with the view to reducing the risks involved in their production and marketing of cocoa are presented in Table 5. Almost half of the farmer (47.5\%) indicated that they have diversified their production system by planting other crops to reduce risks on their land. Crop diversification therefore provided cushion effect and reduced impacts of price and demand fluctuation of cocoa, especially from the international markets. Following crop diversification were $35.0 \%$ of the farmers who indicated that they had gone into nonfarm business to generate additional income. There were very few farmers who indicated that they adopted crop planning and time management $(9.2 \%)$ and adopted new farming technologies $(8.3 \%)$.

\section{Discussions}

Characteristics of cocoa production

The demand for cocoa at international market has increased as a result of the increase in consumption of cocoa products, especially chocolate. However, cocoa farmers are experiencing various risks associated with production and outputs. The risks start with majority of the cocoa plantation dominated by old cocoa trees which are easily attack by pests and diseases. Results obtained from the present study revealed that smallholder farms still dominate the cocoa farms in the study area. Majority of the visited cocoa plantations were inherited by the farmers. Villalobos (1989) reported that many of the cocoa farms in Nigeria were operating at small scale level and majority were over 40 years old. Such farms constituted as much as $60 \%$ of the cocoa farms in the country. In addition, Daramola et al. (2003) discovered that most of the cocoa farms in Ondo and Osun States were very old 
Table 3 Kruskal-Wallis test for the production risks of cocoa in Ondo State Nigeria

$1-10=$ Lowest to highest risk facing production of cocoa

*Significant at $\mathrm{p}<0.001$; $\mathrm{df}=9$

The asterisk simply means the values are significant at $\mathrm{p}<0.05$

\begin{tabular}{llc}
\hline Sources of production risks & Mean & Ranking \\
\hline Damage by pests and diseases & $105.5^{*}$ & 10 \\
Dependent on natural weather condition & $95.5^{*}$ & 9 \\
Lack of subsidies on agrochemicals & $91.5^{*}$ & 8 \\
Expensive inputs & $91.0^{*}$ & 7 \\
Old methods of farming & $90.5^{*}$ & 6 \\
Weak research and extension linkages & $86.5^{*}$ & 5 \\
High maintenance of the farm & $76.0^{*}$ & 4 \\
High cost of production & $72.0^{*}$ & 3 \\
Poor productivity & $71.5^{*}$ & 2 \\
Lack of technical knowledge in production process & $65.5^{*}$ & 1
\end{tabular}

Table 4 Kruskal-Wallis test for the marketing risks of cocoa in Ondo State Nigeria

\begin{tabular}{lll}
\hline Sources of marketing risks & Mean & Ranking \\
\hline Exploitation by middlemen & $101.2^{*}$ & 5 \\
Inconsistence and fluctuation & $93.7^{*}$ & 4 \\
$\quad$ in pricing system & & \\
High marketing cost & $71.9^{*}$ & 3 \\
Low price of product & $70.5^{*}$ & 2 \\
Lack of market information & $60.2^{*}$ & 1 \\
\hline
\end{tabular}

1-5 = Lowest to highest risk facing marketing of cocoa

Significant at $\mathrm{p}<0.001 ; \mathrm{df}=4$

with low productivity. Ndubuto et al. (2010) argued that low productivity experiencing by cocoa farmers is as a result of the ageing of cocoa producing trees, which places the yields of cocoa in Nigeria behind those obtained in Cote d'Ivoire and Indonesia, the two major producers of cocoa in the world. The issue behind the old farms is that majority farmers did not have the means to replant their old farms with improved varieties of cocoa, consequently resulting to their low productivity. The issues of low productivity and return from cocoa farms have forced some farmers to engage in off-farm business activities to meet their personal and domestic needs, while some have diversified their production by abandoning cocoa for other crops which give them immediate profit.

The farmers used old system of farming on their cocoa and relied solely on natural weather conditions for their production. These are other reasons why the farmers were subjected to more risks to the sector. On mode of land acquisition for cocoa production, further discussions with the farmers revealed that public land, such as communal land and land belonging to a family, may not be easily obtained for production of perennial crop like cocoa. Most of the people in the communities were also not ready to lease their land for cocoa production, while restrictions were laid on selling of family and communal lands. The risk of non-return of leased land if used for establishment of cocoa farm affected those that were interested in establishing cocoa plantation or plan to expand their plantation from getting public lands for such venture. Another issue with securing land for establishing cocoa plantation was land fragmentation. As population in families are increasing, the parcel of land belonging to such families is becoming smaller and not enough to establish cocoa farms. In situations where families jointly own a cocoa plantation, such a plantation is leased out. Within this lease period, the holder can only manage the farm and carry out harvesting as stipulated within the agreement. In some situation
Table 5 Coping strategies for risks in cocoa farming in Onda State Nigeria

\begin{tabular}{llc}
\hline Sources of marketing risks & Frequency $(\mathrm{n}=120)$ & Percentage \\
\hline Diversification of the production system & 57 & 47.5 \\
Non-farm business & 42 & 35.0 \\
Crop planning and time management & 11 & 9.2 \\
Adoption of new farming techniques & 10 & 8.3
\end{tabular}


where conflicts frequently occur among the members of the family, such a plantation was sold out and the money shared.

Majority of the cocoa farmers did not apply fertiliser on their farm. The contributions of fertiliser application to cocoa yield have been reported. For instance, a four-year on-farm trials in Ghana by Appiah et al. (1997), showed a doubling of yields after the application of 4.94 bags per hectare of triple super phosphate and 2.47 bags of muriate of potash. In another study, Ruf (2012) found an improvement in the yield of degraded cocoa farms with mature trees in Ghana and Cote d'Ivoire after application of fertilisers for one year. In the pilot study, Ruf (2012) applied two types of fertilisers to plots established on selected degraded cocoa farms with the assumption that this will fight diseases like black pod. At the end of one year, the results of the experiment showed a clear impact on production with increase in the foliage of the degraded cocoa trees, reduction in tree diseases and mortality, higher yield, and higher-quality pods. Major lesson from this experiment is that productivity of degraded cocoa could still be improved through fertiliser application with business opportunities for cocoa sector. However, the issues of affordability and availability of the fertilisers by the local cocoa producers should be properly addressed for this type of technology to be fully adopted.

Risks from pest attack and disease infestation

The issue of phytosanitory in cocoa production is a serious risk (Juhrbandt et al. 2010). Cocoa trees are frequently susceptible to attack by insects and pathogens (CABI Commodities 2004). The most prevalent among these is the fungal disease commonly known as 'black pod' caused by fungi, Phytophthora megakarya and Phytophthora palmivora. Black pod disease is responsible for about $44 \%$ of global loss of cocoa production (Nkamleu et al. 2007). These diseases have caused serious economic loss and damage to cocoa farmers from reduction of productivity to total killing of cocoa trees. Despite this unfortunate economic loss, it has been discovered that black pod is preventable especially with provision of appropriate interventions and timely good management practises in cocoa plantations. However, with low income accrued to the farmers from their production, insects attack and disease infestations persist leaving the farmers with little or no harvest.

\section{Low standard of cocoa beans}

Some of the cocoa beans from Africa are constantly rejected at the international market due to low standard of the beans in meeting the international food safety requirements (Odularu 2011). Quite a number of marketers did not meet the standard guidelines for transportation and shipment of cocoa beans (Wood and Lass 1985; CMAA 2012). The major cause of low quality of the cocoa beans was the use of local and crude processing methods for the cocoa beans. Farmers, in most cases, cannot afford processing equipment and machinery which can produce high quality beans for the international market. The issue of low beans' quality is further compounded by the use of banned chemicals by the cocoa farmers on the beans. At times, chemicals' contaminant with the cocoa beans may either be deliberate or not. For instance, farmers may deliberately apply the banned chemical in treating pests and diseases of beans while in store house, or on the other hand, chemicals kept in store house and not properly handled may spill over the beans thereby causing contamination. Whichever, the case, any sign of contamination of the beans with banned chemicals disqualify such beans at the international market.

Labour issues in cocoa production

Family labour was the highest form of labour among the cocoa farmers. In as much as this has its advantage of little to no cost, it has its negative impacts on children in cocoa producing areas. The use of child labour on cocoa farm has been connected with child slavery and trafficking (Diane and Kirkhorn 2005; ILO/IPEC 2005; Food Empowerment Project 2014). This also contends with education, welfare, and future of children living in cocoa producing communities. A report from UNICEF (cited by Raghavan and Chatterjee 2001) revealed that some Ivory Coast farmers used enslaved children on their plantations. ILO/IPEC (2005) also reported that children worked more than $12 \mathrm{~h}$ per day on cocoa plantations in West Africa and were beaten regularly. In addition, it was reported that one third of the school-aged children living in cocoa producing households had never attended school and 
while only $34 \%$ of children working on cocoa farms attended school (ILO/IPEC 2005). Furthermore, Kenyon (2010) reported that some farmers in Ivory Coast and Ghana were found to stop their children from going to school during harvesting period of cocoa pods. These are major labour issues posing high risk to children in cocoa producing communities, hence a challenge to achieving the Millennium Development Goal (MDG) of education for all.

\section{Risks with respect to demand and price of cocoa}

Pricing issue is constituting high risk and uncertainties for the local ccoa farmers. It has been widely reported that the selling price of cocoa is mainly driven by buyers along the marketing chain (Fold 2002). This has characterised cocoa marketing chain among other agricultural products for a long period of time. The major issue with this is that it leads to exploitation by buyers and leaves the local farmers at the mercy of the price the buyers have to offer. Consequently, the farmers are prevented from benefiting from the increasing profits at the global level. As a result of the strong network of international buyers of cocoa, coupled with the fact that cocoa beans are not processed into final valuable products in the producing communities, strategy to turnaround this buyer-driven price along the cocoa marketing chain is doubtful, and is a call for intervention.

In addition to buyer-driven issue, the price of cocoa is not stable and always fluctuates at international market (Fold 2002). Recently, it was observed that the world market price of cocoa beans has been declining, whereas the profits accrued to the buyers of raw beans and multinational chocolate companies have been increasing (MCF 2013). Despite this increase in the global cocoa demand and profit margin, the impacts are not felt by the local farmers. This is another major concern in the cocoa sector, especially for the producing communities.

\section{Political instability and insurgency}

In the recent time, the production and marketing of cocoa have been affected by other external factors such as political instability as well as turmoil in the producing states. Political insurgencies is leading to non-conducive environment for the producers to operate, thereby affecting international trade. This is also leading to lack of appropriate policy formulation, coordination of the marketing system, and enforcement of international market standard and regulation.

\section{Potential benefits of developing cocoa sector}

There is huge potential in cocoa sector from production to processing into value added products. Cocoa producing countries can benefit from local processing opportunities through diversification and value addition along the marketing chain. A country like Nigeria can further develop this sector into non-oil revenue generation. Most especially, development of the cocoa sector can generate multiplier effects at the local level, some of these include job creation, springing up of local enterprises, improvement in household income, and increase of general rural economy. It is high time that all these benefits are tapped into by cocoa producing countries, especially in West Africa where the production is at the highest. It has been reported that communities where cocoa are produced are underdeveloped and the farmers are living in abject poverty.

\section{Conclusion}

The study has shown a number of risks associated with cocoa production and marketing in Nigeria. All the evaluated production and marketing risks among the farmers were significant. Moreover, ranking on top of the production risks was risks relating to pests and diseases attack while that of marketing was exploitation by the buyers (exporters). Other important factors constituting risks to marketing of cocoa was price fluctuations. The price of cocoa is mainly determined at the international market and final price by the buyer with very little influence by the local farmers. It is pertinent that the local market of cocoa beans is well developed to reduce over reliance on international markets, and fluctuating global prices. There is need for government intervention especially in creating policy and setting other legal frameworks that make price risk management tools accessible to farmers.

Government should specifically put in place a marketing scheme targeted at assisting farmers in marketing their beans through price regulation and monitoring, and enforcement of standard. Strategy for proper implementation of the promulgated Export Processing Zones Decree No. 34 should be put in 
place. Efforts should be made to revive and improve the operations of Export Processing Factories for full achievement of the targeted benefits.

Most importantly, the government of Nigeria should make a deliberate effort to review the existing policies that only favour the exporters of cocoa beans at the expense of the local farmers. Nigeria, as well as other producing states in West Africa, stands to gain from activating a deliberate policy to make valueaddition of the raw cocoa beans. This should be properly and adequately addressed and made a key part of national policy. Better production practices against pests and diseases management, and other cultural practices are pertinent in cocoa production system to minimize the threats of unsustainable production.

To attain the goals of risks reduction in the face of economic development and poverty alleviation, cocoa farmers should be empowered and assisted with incentives that will allow them to acquire necessary farm inputs in meeting international standards. The farmers need to be taught the current technologies of cocoa production with the provision of necessary incentives such as improved varieties of cocoa seedling, fertiliser and approved pesticides, financial assistance, and simple processing technologies that produce standard cocoa beans. If these are well implemented and monitored, more opportunities will be created at the local level and attract involvement of new educated young farmers. When the rural areas are filled with job opportunities such as cocoa value addition enterprises, there will be reduction in ruralurban migration, and serve as mitigation for overpopulation of cities.

\section{References}

Adegeye AJ (1996) Production and marketing of cocoa in Nigeria: Problem and solution. Proceedings of National seminal on revolutionalising Nigeria's cocoa industry, Ibadan, Nigeria

Adekunle VAJ, Olagoke AO, Akindele SO (2013) Tree species diversity and structure of a Nigeria strict nature reserve. Trop Ecol 54(3):275-289

Almeida I, Monnier O (2013) Higher chocolate prices may follow africa's cocoa shortfall. Business week February 07, 2013. http://www.businessweek.com/articles/2013-02-07/ higher-chocolate-prices-may-follow-africas-cocoa-shortfall. Accessed 14 Mar 2014
Appiah MR, Ofori-Frimpong K, Afrifa AA, Asante EG (1997) Prospects of fertilizer use in the cocoa industry in Ghana. Proc Soil Sci Soc Ghana 15:215-221

Cadoni P (2013) Analysis of incentives and disincentives for cocoa in Nigeria. Technical notes series, MAFAP, FAO, Rome

Cocoa Merchants' Association of America (CMAA) (2012) Standard guidelines for shipment of cocoa beans in containers. The Cocoa Merchants' Association of America, Inc

CABI Commodities (2004) Developing sustainable cocoa production systems. http://www.cabi.org/datapage.asp?iDocID= 210. Accessed 11 Nov 2005

Daramola AG, Fuwape JA, Ofuya TI, Okunlola JO, Ajibefun IA, Okuku IE, Oke DO, Aladesaiye E, Badaru KB, Olaiya AO (2003) Evaluation of sustainable options for rehabilitation for small holder nigerian farmers. Sustain Compet Cocoa Syst Africa Econ 16:47-53

Diane L, Kirkhorn SR (2005) Child labor in ghana cocoa production: focus upon agricultural tasks, ergonomic exposures, and associated injuries and illnesses. Pub Health Rep 120(6):649-656

European Union Food Information Council (EUFIC) (1999) A sustainable future for cocoa. FOOD TODAY 05/1999. http://www.eufic.org/article/en/food-safety-quality/farm-tofork/artid/sustainable-future-cocoa/. Accessed 12 Mar 2014

Fantazy KA, Kumar V, Kumar U (2010) Supply management practices and performance in the Canadian hospitality industry. Int J Hosp Mgt 29(4):685-693

Fold N (2002) Lead firms and competition in 'Bi-polar' commodity chains: grinders and branders in the global cocoachocolate industry. J Agra Chang 2(2):228-247

Food Empowerment Project (2014) Slavery in the Chocolate Industry. http://www.foodispower.org/slavery-chocolate/. Accessed 13 Mar 2014

Forest Trends and the Ecosystem Marketplace (FTEM) (2008) Payments for ecosystems services: market profiles. http:// ecosystemmarketplace.com/documents/acrobat/PES_Matrix_ Profiles_PROFOR.pdf. Accessed 13 Mar 2014

Gockowski J (2007) Cocoa production strategies and the conservation of globally significant rainforest remnants in Ghana. Paper presentation. Overseas Development Institute and International Food Policy Research Institute

Hamzat RA, Olaiya AO, Sanusi RA Adedeji AR (2006) State of cocoa growing, quality and research in nigeria: need for intervention. A technical presentation at the Biannual Partnership Programme of the World Cocoa Foundation, Brussels, Belgium

ICCO (2013) Production of cocoa beans. The International Cocoa Organisation (ICCO) Quarterly Bulletin of Cocoa Statistics, Vol. XXXVIII, No. 3. http://www.icco.org/ about-us/icco-news/210-november-2012-quarterly-bulletinof-cocoa-statistics.html. Accessed 14 Mar 2014

ILO/IPEC (2005) Combating child labour in cocoa growing. International Programme on the Elimination of Child labour (IPEC). International Labour Organisation, Geneva. http://www.ilo.org/public//english/standards/ipec/themes/ cocoa/download/2005_02_cl_cocoa.pdf. Accessed $13 \mathrm{Mar}$ 2014 
Juhrbandt J, Duwe T, Barkmann J, Gerold G, Marggraf R (2010) Structure and management of cocoa agroforestry systems in Central Sulawesi across an intensification gradient. Envtal Sci Engr, pp 115-140

Kenyon P (2010) Tracing the bitter truth of chocolate and child labour. BBC/Panorama, 24 March, 2010. http://news.bbc. co.uk/panorama/hi/front_page/newsid_8583000/8583499. stm. Accessed 13 Mar 2014

Lawong KE (undated) Main Risks in Cocoa Sector of Cameroon. Enterprise Risk Management Academy. https://www. erm-academy.org/publication/risk-management-article/ main-risks-cocoa-sector-cameroon. Accessed 13 Mar 2014

Make Chocolate Fair (MCF) (2013) Cocoa prices and income of farmers. European Campaign for Fair Chocolate. http:// makechocolatefair.org/issues/cocoa-prices-and-incomefarmers-0. Accessed 13 Mar 2014

Ndubuto NI, Agwu N, Nwaru J, Imonikhe G (2010) Competitiveness and determinants of cocoa export from Nigeria. Report Opin 2(7):51-54

Nkamleu GB, Keho Y, Gockowski J, David S (2007) Investing in agrochemicals in the cocoa sector of Côte d'Ivoire: hypotheses, evidence and policy implications. Afr $\mathrm{J}$ of Agric Res Econ 1(2):145-166

Odularu GO (2011) The role of standards in influencing Ghana's access to global market for cocoa. Intl J Afro-Asian Stud 2(2): 17-29

Oke DO, Odebiyi KA (2007) Traditional cocoa-based agroforestry and forest species conservation in Ondo State, Nigeria. Agric Ecosyts Envt 122:305-311

Otchere AF, Annan J, Quansah E (2013) Assessing the Challenges and Implementation of Supply Chain Integration in the Cocoa Industry: a factor of Cocoa Farmers in Ashanti Region of Ghana. Int J Bus Soc Sci 4(5):112-123

Raghavan S, Chatterjee S (2001) A Taste of Slavery. Knight Ridder Newspapers. June 24, 2001. http://vision.ucsd.edu/ $\sim$ kbranson/stopchocolateslavery/atasteofslavery.html. Accessed 13 April 2014

Ruf F (2012) Cocoa and fertilisers in West Africa. IDH. http:// www.idhsustainabletrade.com/site/getfile.php?id=248. Accessed 17 Mar 2014

Sarpong KO, Alexander OF, Anin EK (2013) An assessment of supply chain risks in the cocoa industry in the Ashanti Region, Ghana. Int J Human Soc Sci 3(19):191-201

Vigneri M (2007) Drivers of productivity growth in Ghana's cocoa sector between 2001 and 2003. Paper presentation. Overseas Development Institute and International Food Policy Research Institute, November 19, Accra, Ghana

Villalobos VM (1989) Advances in Tissue Culture Methods Applied to Coffee and Cocoa Plant Biotechnology for Developing Countries. CTA/FAO Symposium on Plant Biotechnologies for Developing Countries. Luxembourg. FAO, Rome

Wayne DW (1990) Applied Non-parametric Statistic, 2nd edn. PNS-Kent Publishing Company, Boston

Wood GAR, Lass RA (1985) International Cocoa Standards, Fourth Edition. Longman Group Ltd

World Cocoa Foundation (WCF) (2012) Cocoa Market Update. March 2012. http://worldcocoafoundation.org/wp-content/ uploads/Cocoa-Market-Update-as-of-3.20.2012.pdf. Accessed 16 Mar 2014 